Article

\title{
From Hispanisms to Anglicisms: Examining the Perception and Treatment of Native Linguistic Features Associated with Interference in Translator Training
}

\author{
Carlos I. Echeverría ${ }^{1,2, *}$ and César A. González-Fernández ${ }^{2}$ \\ 1 Department of Spanish, Italian and Portuguese, The Pennsylvania State University, \\ University Park, PA 16802, USA \\ 2 Programa de Traducción Inglés-Español, Universidad Chileno-Británica de Cultura, Santiago, Chile; \\ cesar.gonzalez@usach.cl \\ * Correspondence: cecheverria@psu.edu
}

Received: 16 April 2019; Accepted: 17 June 2019; Published: 19 June 2019

\begin{abstract}
In this study, translation students and instructors at Chilean universities were asked about their perception and treatment of five grammatical features of Spanish, which, despite constituting Hispanic developments independent of any English influence, have been often associated with anglicisms in the translation literature. Numerous responses were recorded labeling the features under consideration as unacceptable and/or as anglicisms, as well as indicating generalized unfavorable attitudes toward these features in the classroom. Additionally, a significant association was found between feature acceptability and both purported relation to English and self-reported instructor attitudes in the classroom, such that when a feature was labeled as an anglicism it would most likely elicit a negative judgment. Together, these results show that some students and instructors tend to strongly associate certain features with a negative value and with the idea of anglicism. Furthermore, taking participants' responses at face value, this association could be interpreted as involving a categorical stigmatization and xenofication of the respective features. From a pedagogic perspective, these findings are considered worthy of attention as they indicate the possible stigmatization and xenofication of potentially useful linguistic resources in translator training, something that may have negative consequences for trainees.
\end{abstract}

Keywords: translator training; language beliefs and attitudes; English-Spanish translation; linguistic interference; anglicisms

\section{Introduction}

Modern reflections on translation (understood as encompassing both written and oral interlingual mediation) have given great attention to translators' tendencies to imitate the source text and language beyond what could be considered acceptable or adequate. In this area, many have been the scholars concerned with phenomena of linguistic interference, which Weinreich (1968) famously defined as "[t]hose instances of deviation from the norms of either language which occur in the speech of bilinguals as a result of their familiarity with more than one language" (p. 1). This can be easily confirmed by entering the term interference, as well as related terms such as false friends, anglicism, etc., in Franco Aixelá's (2019) translation and interpretation bibliographic database. 
The idea of interference-it is well known—has been historically associated with a rather negative value, which has tended to become overt in prescriptive publications and in pedagogic settings concerned with the learning and use of foreign languages (see Blas Arroyo 1991, p. 267; Musacchio 2005, p. 72). A clear example of this in the field of translation studies is Vázquez-Ayora's (1977) famous introduction to the discipline and to English-Spanish translation, in which we read that interference brings nothing but "errors, literalism, and unintelligibility,"1 and that translators must "fight relentlessly" (p. 45) against it. As may be expected, this view has had an important impact on the research agendas of scholars interested in the topic in the field of translation (as it has in applied linguistics as traditionally defined), interference often having been tackled as something to detect, denounce, and remediate.

In the present paper, we consider interference from a rather different perspective. We ask whether, under certain circumstances, the perception and treatment of particularly well-known interference phenomena may extend to entire linguistic classes that, despite not being interferential per se, hold a relation to said phenomena. Specifically, we set out to investigate, in the Chilean translator training context, whether and to what extent certain features of the Spanish language have gone from simply being known to be (extricably) related to anglicisms, to becoming subject to negative bias and to being treated as anglicisms in themselves. To this end, translation students and instructors at Chilean universities were asked about their perception of five grammatical features often mentioned in the literature on English-Spanish translation as well as about the treatment those features receive in the classroom.

The remainder of the text is organized as follows: In Section 2, we start by defining some key notions. In Section 3, we briefly describe our motivation and contextualize the research by referring to previous work having to do directly or indirectly with our subject of study. In Section 4, we detail the criteria and procedures used in the study, referring to the participants, the linguistic features under consideration, and the design and use of materials for data collection. In Section 5, we present and discuss our results. Finally, in Section 6, we close with a recapitulation and a set of concluding remarks on our main findings, including possible directions for future research.

\section{Key Notions}

In this paper we adopt a relatively broad notion of (linguistic) interference. Specifically, interference is here understood-not too far from Weinreich's original conception-as a deviation from the local language occurring in the discourse of a bilingual, due precisely to his or her bilingual condition. The term local language in this definition refers to what Coseriu (1982a, pp. 313-14) calls the idiomatic context, i.e., a previously constituted language state, considered as both a functional system and a norm (see Coseriu 1982b), serving as the context, as the background, of an utterance or series of utterances. Consequently, we will treat as interference phenomena deviations pertaining to both the level of the functional system and of the norm of the pertinent language, both of a qualitative and of a quantitative nature, and involving both cross-linguistic convergence and divergence (see Coseriu 1977, pp. 97-99; Kabatek 1997, pp. 236-38; Echeverría Arriagada 2016b, pp. 100-5).

We prefer the term interference to cross-linguistic influence and transfer, which are also common in the broad multilingualism literature. The reason for this is that the latter two terms are usually used to highlight psycholinguistic processes (see Anderman and Rogers 2005; Kellerman and Smith 1986; Odlin 1989), whereas here, in accordance with Weinreich, we are highlighting a particular type of linguistic outcome. On the other hand, although some translation scholars do not draw a clear distinction between the two phenomena (e.g., Castillo Lluch 2005; Del Rey Quesada 2017; Newmark 1991; Toury 1995), here we wish to emphasize the different nature of interference, as defined above, and source-text influence on the translator's expressive choices in general. Even though the latter can certainly lead to the former, there is by no means an implicational relation between the two.

1 All quotes from works in languages other than English have been translated by us. 
For example, a translator can calque an expression or phrase of the source text and yet produce a perfectly idiomatic outcome in the target language (see García Yebra 1985, p. 157; Newmark 1988, p. 72)2.

As to the term anglicism, we will use it to refer, in principle, to any case of interference involving cross-linguistic convergence ${ }^{3}$ where the source is (a variety of) English, though in these pages we will deal specifically with anglicisms occurring in Spanish-speaking contexts.

Having defined these notions, we can proceed to draw a distinction between two types of links a linguistic entity can hold to interference which are especially relevant to our study.

On the one hand, there exist linguistic entities that are in themselves interference phenomena. Imagine, for example, an adjective formed by the phonic sequence [ak'twal] with the meaning 'real, existing in fact,' produced in an English-influenced slip, due to the "false friendship" (see Granger and Swallow 1988, Koessler and Derocquigny 1928) that exists between English actual and the Spanish homograph meaning 'current, present-day,' by an English-Spanish bilingual communicating with a group of Spanish speakers with no knowledge of English. Under these circumstances, such a word, let us label it actual $_{\text {angl, }}$, would clearly constitute an anglicism, since in Spanish/actual/corresponds to a strictly temporal word, of which actual $_{\text {angl }}$ could not possibly be considered a variant. ${ }^{4}$

On the other hand, some linguistic entities do not constitute interference phenomena in themselves, yet they are still related to such phenomena. Thus, to continue with the same example, Spanish actual, unlike actual $_{\text {angl, }}$, constitutes a Hispanic development that had nothing to do with English, and which is perfectly normal in Spanish-speaking territory, so it could not possibly be said to be an anglicism. But, even without constituting an anglicism in itself, this word does hold a relation to anglicism phenomena, even if an extricable one, insofar as its "false friendship" with English actual can be said to play a role in the occurrence of actual $l_{\text {angl }}$.

Another example of a linguistic element that is not interferential per se and yet is related to interference phenomena is, moving now to the domain of grammar (which is our focus in this paper), the Spanish gerund. This grammatical class, considered in its essential defining aspects in the system found in most varieties of Spanish, constitutes a perfectly normal feature of the common language, which originated with total independence from English, so, naturally, it cannot be an anglicism per se. Nevertheless, many scholars have drawn a connection between the Spanish gerund and anglicisms (e.g., Aguado de Cea 1990, p. 166; Gili Gaya 1980, p. 114; López Guix and Wilkinson 1997, pp. 123-24; Marcos Pérez 1971, p. 51; Molina Plaza 1995, p. 625; Serna 1970, p. 841; Smith 1997, p. 26; Vázquez-Ayora 1977, pp. 106-7). For example, because English -ing forms can function both as adverbs and as nouns, when dealing with these signs novice translators into Spanish sometimes produce nominal gerund-looking forms where normally an infinitive would be used, as illustrated in (1): ${ }^{5}$

2 A reviewer mentions a lack of clarity regarding the relationship between interference as understood in disciplines such as sociolinguistics, applied linguistics, and translation studies. However, even if the term interference has historically been used in different senses in different disciplines, here we have provided a precise definition that can be applied in all the aforementioned disciplines. On the other hand, the phenomena dealt with in these disciplines will obviously often show important differences. Thus, for example, the psycholinguistic processes leading to interference in regular monolingual conversation and in simultaneous interpretation are likely to be quite different, since the first situation involves processing and producing only one language, while the second involves a constant alternation between different languages between processing and production. Yet these differences should be irrelevant for the purposes of the present paper, so long as the phenomena in question can be said to be interferential according to our definition.

3 In cases of cross-linguistic divergence, it is more appropriate to speak of antianglicisms (see Del Rey Quesada 2017, pp. 678-79; Echeverría Arriagada 2016b, pp. 109-10; Lorian 1967, p. 168).

4 A key underlying distinction here is that between linguistic signs-defined in terms of a signifier and a signified, to use De Saussure's (2011) terms - and mere phonic forms. As signs, Spanish actual and actual ${ }_{\text {angl }}$ are distinguished from each other by different meanings; therefore, they must be treated as different linguistic entities.

5 The distinction made in the previous note also applies to grammar. Thus, in the case of these gerund-looking forms, we can say that the language user is using phonic forms that normally correspond to Spanish gerunds, but not that he or she is using actual Spanish gerunds, since this grammatical class (as it exists in Spanish) is defined not only by a phonic form, but also (and most importantly) by a particular grammatical meaning. 
(1) $\quad\left\{\right.$ Ejercitar $/{ }^{*}$ Ejercitando $\}$

\{Exercise-INF/Exercise-PSEUDOGER\}

'Exercising every day is the best.'

$\begin{array}{lllll}\text { cada día } & \text { es lo mejor } \\ \text { every day } & \text { is the best }\end{array}$

Thus, we can say that the Spanish gerund also holds a relation to anglicism phenomena, despite not being an anglicism per se.

The distinction between linguistic entities that are in themselves interferential and linguistic entities that are merely related to interference phenomena may seem obvious. However, as will be shown in the following section, some authors have failed to keep the two phenomena clearly separate. Thus, an articulation of the distinction is pertinent.

\section{Background and Motivation}

As far as we are aware, the first to suggest the existence of a phenomenon like the one we are interested in here was Echeverría Arriagada (2011), in a paper on the use of Spanish -mente adverbs in English-Spanish translation. According to this author, the premise that these adverbs can bring problems to unwary translators who use them each time they find a morphologically similar word in the source text, and the frequency with which these problems have been mentioned or implied in the literature (e.g., García González 1998, p. 615; García Yebra 1984, p. 366; Lorenzo 1996, p. 92; Ramón and Labrador 2008, pp. 275-77; Rodríguez Medina 2002, pp. 161-62; Vázquez-Ayora 1977, p. 116), are likely to have led some translation scholars and instructors to become biased against these forms, even though these forms constitute legitimate, internally-developed expressive resources in Spanish. As an example, Echeverría Arriagada mentions the case of Rochel and Ortega (2008), who in a book on French-Spanish translation label -mente adverbs as "unstylish" (p. 124), despite the fact that from the very beginning these forms have been characteristic of written, educated language (see Company Company 2012; Domínguez de Rodríguez-Pasques 1970, p. 295), and he also reports, anecdotally, having noticed a similar bias in several translation instructors in personal interactions both as a student and later as a fellow educator.

It is also easy to find publications that, without necessarily using negative epithets like Rochel and Ortega do, and without showing an outright proscriptive intent, use wordings that may well discourage their readers from using certain linguistic features that are seen as problematic due to their relation to interference phenomena. Take the example of passive constructions with ser ('to be') + past participle, which on many occasions have been associated with interference and particularly with anglicisms (e.g., Aguado de Cea 1990, p. 166; Arauz 1992, p. 182; García González 1998, pp. 609-13; García Yebra 1984, pp. 369-70; Gili Gaya 1980, pp. 122-23; Lorenzo 1991, p. 78; López Guix and Wilkinson 1997, p. 136; Montes 2002, pp. 116-17; RAE = Real Academia Española 1973, p. 451; Rodríguez Medina 2002, pp. 157-64; Smith 1997, p. 26; Vázquez-Ayora 1977, pp. 107-9). For instance, García Yebra (1984) writes in his well-known general treatise on translation that "when translating from English, German, or French into Spanish, it is convenient, in principle, to replace the passive voice with the active" (p. 210), even if in other places he acknowledges the independent existence and utility of these constructions in Spanish. Likewise, in Claros Díaz's (2016) recent scientific translation and writing manual, even if the author points out that these constructions are "not incorrect at all" (p. 90), this statement appears under the rather categorical heading "Avoid the passive voice."

Moreover, in some cases one can encounter the objectionable practice of using terms such as anglicism or gallicism to refer directly to linguistic features that certainly are not anglicisms or gallicisms in themselves. Such is the case, reported by Echeverría Arriagada (2016b), involving the Spanish term anglicismo de frecuencia ('frequency anglicism'), originally intended to denote cases where the frequency of use of a certain feature of the pertinent language system increases due to English influence. As noted by Echeverría Arriagada, some translation scholars have used this term in such a way that it seems as though the features under consideration were anglicisms in themselves, even if in actuality they constitute well-documented Hispanic developments. An example mentioned by this author 
is Rodríguez Medina's (2002) study on frequency anglicisms in translations of computer manuals from English to Spanish. The conclusion of Rodríguez Medina's article states that "adjectives placed before the noun,-mente adverbs, the gerund, unnecessary repetitions, and the verb poder are syntactic frequency anglicisms" (p. 166; emphasis ours), an unfortunate wording considering that all mentioned linguistic resources have been attested in Spanish with independence from any English influence. And a similar example is found in the very title of Véliz Ojeda and Cámara Cámara's (2010) paper “La 'parataxis' como anglicismo de frecuencia" ("Parataxis" as a frequency anglicism'), the wording of which is not fortunate either, given that parataxis has been attested in Spanish since its origins, as it was attested in Latin. ${ }^{6}$

In a first attempt to study directly the perception of these linguistic features in the translator training context, Echeverría Arriagada (2016a) surveyed 30 Chilean English-Spanish translation students with the goal of describing their attitudes and alternative preferences when faced with four types of grammatical elements of Spanish that had been reported to be related to anglicisms in the literature, namely prenominal adjectives, -mente adverbs, passive constructions with the ser, and constructions with poder + infinitive. Although the author was more interested in students' preferences for substituting the linguistic elements in question than in attitudes in themselves, which were used mainly as a pretext to record the former, his results in this connection are worthy of attention. The attitudes recorded, which were elicited showing participants different variants of the features under consideration, with no labels, were mostly favorable; interestingly, however, the lowest-rated group, as well as the group with the highest substitution rate, were passive constructions with ser, which—as noted by the author-correspond to the Spanish elements about which translators seem to have been warned most often in the literature dealing with English-Spanish translation (see the list of references cited above). Thus, despite the generally favorable attitudes recorded in this study, these results may be taken as suggesting a possible influence of the way the respective features have been treated by those we may regard as "translation authorities."

Now, if certain native linguistic features may go from merely being associated with interference phenomena to becoming subject to negative bias because of that, this could potentially lead to various problems in the context of translation, especially for novices. In addition to involving the stigmatization and xenofication ${ }^{7}$ of valid linguistic resources, such a phenomenon may result in difficulties, unideal solutions, and even mistakes when translating (see Kussmaul 1995, pp. 17-20). Imagine, for example, an English-Spanish translation student too scared of using passive constructions with ser + past participle due to fear of anglicisms. In addition to taking more time in his or her attempt to avoid these constructions, this student could for instance end up rendering a sentence like (2) as (3b), instead of the perfectly acceptable (3a), using the so-called "reflexive passive" despite the fact that this alternative is odd when there is an explicit agent. ${ }^{8}$

6 Echeverría Arriagada (2016b, p. 110) provides a useful analogy for understanding the problem. If a frequency anglicism is defined in strictly statistical terms, as the relative overuse of a linguistic element of the local or target language due to English influence, then referring to the linguistic elements involved in this type of phenomenon as though they were anglicisms in themselves is comparable to confusing a fish with its shoal.

7 We use the term xenofication (suggested to us by Trevor Bero) to refer to the action of treating something (e.g., a linguistic feature) as foreign or alien to the local environment (see Jaspert 2015, p. 6). The notion of xenofication, thus defined, should not be confused with that of foreignization, which has to do with "how much a translation assimilates a foreign text to the translating language and culture, and how much it rather signals the differences of that text" (Venuti 1998, p. 102).

8 This is something we have seen in person several times in the translation classroom. Of course, here one could also use an active sentence like Los alemanes construyeron la iglesia a comienzos del siglo XIX ("The Germans built the church in the early 19 th century'). However, this option would not preserve the order of the original, something one might want to do for pragmatic reasons. On the other hand, a sentence like La iglesia la construyeron los alemanes a comienzos del siglo XIX could have an undesired focalizing effect. 
(2) The church was built by the Germans in the early $19^{\text {th }}$ century.

(3) a. La iglesia fue construida por los alemanes a $\begin{aligned} & \text { comienzos } \\ & \text { The church was built } \\ & \text { del siglo XIX }\end{aligned}$
of.the century 19
b. \#La iglesia se construyó por los alemanes a
The church REFL built
del siglo XIX the Germans at beginnings
of.the century 19
'The church was built by the Germans in the early $19^{\text {th }}$ century.'

Thus, research on this largely underexplored topic seems justified from a pedagogic perspective.

\section{Method}

\subsection{Participants}

The student group surveyed in this study consisted of 86 third- and fourth-year English-Spanish translation students at three Chilean universities. ${ }^{9}$ As an incentive, all students were offered to participate in the giveaway of seven department store gift cards. The instructor group consisted of 17 current or former English-Spanish translation instructors, whose affiliations include nine Chilean universities in total. The requirement for former instructors was to have taught English-Spanish translation at the university level in the past five years. Participation in this case was voluntary, and no compensation was offered. The acquisition and handling of all participant data followed the stipulations and guidelines of the Universidad Chileno-Británica de Cultura Research and Ethics Committee, which approved the study on June 14, 2017.

\subsection{Linguistic Features}

The selection of the linguistic features to be considered in this study was based principally on Rodríguez Medina's (2002) selection in her research on frequency anglicisms. Five types of elements were selected, namely gerunds, prenominal adjectives, mente adverbs, passive constructions with ser + past participle, and constructions with poder + infinitive, illustrated in (4-8) respectively: ${ }^{10}$

(4) Encontré a Pablo bailando en la calle

I.found ACC Pablo dancing in the street

'I found Pablo dancing in the street.'

9 Only in one of these institutions were students trained in a third working language.

10 Naturally, space constraints make it impossible to delve into the peculiarities of these types of linguistic elements in Spanish, which in any case are not relevant for our purposes. For a general characterization, see, (e.g., Alarcos Llorach 1969, 1999; Bosque and Demonte 1999; Gili Gaya 1980; RAE/ASALE = Real Academia Española and Asociación de Academias de la Lengua Española 2009). 
(5) Este es un hermoso día

This is a beautiful day

'This is a beautiful day.'

(6) Marcelo escapó rápidamente después del choque

Marcelo escaped quickly after of.the crash

'Marcelo escaped quickly after the crash.'

(7) Esta institución fue creada en 1950

This institution was created in 1950

'This institution was created in 1950.'

(8) Necesitas inscribirte para poder participar en el concurso

You.need register to can participate In the contest

'You need to register to be able to participate in the contest.'

These features were chosen based on two conditions. On the one hand, they all correspond to grammatical features of Spanish which have on several occasions been reported to be linked to anglicisms in situations of contact between Spanish and English, especially in English-Spanish translation, being used abnormally at an individual-token level, providing a phonic form for functions normally not associated with it, or simply being used with higher frequencies than normal ${ }^{11}$ (see, e.g., Aguado de Cea 1990; Alcaraz Varó and Martínez Linares 1997; Arauz 1992; Calvo Montoro 1983; García González 1998; García Yebra 1984; Echeverría Arriagada 2011; Lázaro Carreter 1997; Lorenzo 1996; López Guix and Wilkinson 1997; Marcos Pérez 1971; Molina Plaza 1995; Montes 2002; Pratt 1980; Rabadán et al. 2006; RAE = Real Academia Española 1973; Ramón and Labrador 2008; Rodríguez Medina 2002; Serna 1970; Smith 1997; Vázquez Orta 1986; Vázquez-Ayora 1977). On the other hand, despite their (purported) relation to anglicisms, they all constitute Hispanic developments whose origin had nothing to do with English. ${ }^{12}$

\subsection{Materials}

The data were collected by means of two electronic closed-question questionnaires (one for students and one for instructors; see Supplementary Materials) asking participants directly about the perception and treatment of the features under consideration, which were identified explicitly. The reason for doing this-instead of, for instance, having participants respond to a set of sentences without providing a label for the features of interest (cf. Echeverría Arriagada 2016a) —is that here we are interested precisely in the participants' explicit knowledge and beliefs about these features, as well as in how these features are treated in the classroom (particularly by instructors).

In an attempt to make the questionnaires as easy to understand and answer as possible and thus keep responses on target, in each question introducing a feature we included a label, a definition, and two examples, or, when the label was considered to be self-explanatory enough, only a label and two examples. The goal was that in subsequent questions about the same feature participants could rely

11 On the distinction between these different phenomena of qualitative and quantitative interference, see Echeverría Arriagada 2016b, pp. 103-104. It should be noted that the distinction is sometimes not made consistently. This seems to be the case, for example, in Rodríguez Medina's (2002) study, since, after distinguishing between frequency anglicisms and "innovative" anglicisms, the author says that "[w]hen the gerund becomes a syntactic frequency anglicism, due to its repetitive use, it appears in certain contexts carrying functions that are alien to it" (p. 162).

12 It should be noted that in focusing on these types of elements we are not making any assumptions about English-Spanish equivalences or correspondences (or the lack thereof). 
just on the label or an abbreviation or variant thereof. The labels, definitions, and examples used (as translated into English) were the following:

1. Label: Gerunds. Definition: Impersonal verbal forms that in Spanish end with -ndo. Examples: jugando ('playing'), bailando ('dancing').

2. Label: Adjectives placed before the noun. Definition: N/A. Examples: hermoso dia ('beautiful day'), altos edificios ('tall buildings').

3. Label: Adverbs with the ending -mente. Definition: N/A. Examples: rápidamente ('rapidly, quickly'), efectivamente ('effectively, indeed').

4. Label: Passive constructions. Definition: Any sentence with the verb ser + participle where the grammatical subject assumes the role of the patient. Examples: La iglesia fue construida a comienzos del siglo XVIII ('The church was built in the early 18th century'), Pedro fue regañado por su madre ('Pedro was scolded by his mother').

5. Label: Constructions with the verb poder + infinitive. Definition: N/A. Examples: Al fin podré comer ('Finally I'll be able to eat'), Para poder participar hay que estar inscrito ('In order to be able to participate one must have signed in').

The fact that these labels and definitions did not always follow the same criteria is due to practical reasons. For example, passive constructions were considered more difficult to identify than gerunds without examples of full sentences and without a rather technical definition referring to both grammatical and semantic factors. Thus, passive constructions received such a definition and examples while gerunds received a rather general definition and single-word examples. In any case, it must be taken into consideration that the participants are individuals whose occupation involves extensive efforts not only toward learning the relevant languages but also toward reflecting about them, as well about language in general, from a scientific or quasiscientific standpoint. This, together with the already-mentioned fact that reference to these features has been commonplace in discussions about English-Spanish translation, makes it safe to assume that they will not be alien to the respondents as an object of reflection. Furthermore, even acknowledging the possibility that different individuals may have been exposed to different definitions of the features, these definitions should overlap to a significant extent, and in any case the definitions and examples provided in the questionnaires should help determine the object of consideration to a sufficient extent. Still, in the description introducing the informed consent section of the questionnaire, participants were encouraged to ask the researchers questions in case they had any doubts about any aspect of the study.

As regards the principal questions, in the case of the student questionnaire they consisted, for all five features, in a question about the behavior perceived in instructors, one about the relation of the features to English, and one about feature acceptability. The models followed by these questions and the respective options are listed below:

1. Question: \{Regarding the use of [label], understood as [definition]/Defining [label] as [definition]/ Regarding the use of [label]\}, which of the following options corresponds to your experience as a translation student? Options: (a) In general, my instructors have promoted the use of [label] in Spanish or have shown a favorable attitude toward this type of \{forms/constructions\}; (b) In general, my instructors have not referred to the possibility of using [label] in Spanish or have shown a neutral attitude toward this type of \{forms/constructions\}; (c) In general, my instructors have discouraged the use of [label] in Spanish or have shown an unfavorable attitude toward this type of \{forms/constructions\}; (d) My instructors' attitudes toward the use of [label] in Spanish have been rather heterogeneous. 
2. Question: Defining an anglicism as any linguistic use coming from English or that imitates uses characteristic of this language ${ }^{13}$, would you agree to call [label] as anglicisms? Options: (a) Yes; (b) No; (c) I am not sure.

3. Question: Personally, do you consider the use of [label], in general, to be acceptable when writing in Spanish and when translating from English to Spanish? Options: (a) Yes; (b) No.

In the case of instructors, the questionnaire included, again for all features, a question about the respondent's own classroom behavior, one about the relation of the features to English, and one about feature acceptability. Below are the models followed by these questions with their respective options:

1. Question: \{Regarding the use of [label], understood as [definition]/Defining [label] as [definition]/ Regarding the use of [label]\}, which of the following options corresponds to your behavior as a translation instructor? Options: (a) In general, I promote the use of [label] in Spanish or show a favorable attitude toward this type of \{forms/constructions\} with my students; (b) In general, my attitude toward [label] in Spanish is neutral; (c) In general, I discourage the use of [label] in Spanish or show an unfavorable attitude toward this type of \{forms/constructions\} with my students.

2. Question: Defining an anglicism as any linguistic use coming from English or that imitates uses characteristic of this language, would you agree to call [label] as anglicisms? Options: (a) Yes; (b) No; (c) I would not know.

3. Question: Personally, do you consider the use of [label], in general, to be acceptable when writing in Spanish and when translating from English to Spanish? Options: (a) Yes; (b) No.

The questionnaires were designed with the intention of forcing participants to think of the respective features at the most abstract level possible, as linguistic classes, considered only in terms of their essential defining aspects. Thus, the goal was set to avoid questions and options that could foster reports related specifically to particular, potentially abnormal or normatively incorrect instances of the features or of their phonic forms. ${ }^{14}$ This is the main reason why the items about the relation of the features to English and about their acceptability did not allow for any nuances in participants' responses (e.g., "Acceptable, as long as used according to the precepts of the Royal Spanish Academy" or "Often an anglicism").

We are aware that by not allowing for such nuances we took the risk of preventing participants from including in their responses information that they may have liked to share and that may have told us more about their beliefs and attitudes. We are also aware that by doing this we took the risk of having some participants provide responses that did not entirely reflect their true beliefs and attitudes. Thus, for example, when responding that a given feature was an anglicism, an individual might have been trying to say that it can be, or that it often is, used in an anglicized way. Regarding the first issue, it should be noted that every study will have a more or less arbitrary cut-off point for how much information it will actually seek to gather, which will be determined by the objectives of the study but also by the fact that the amount of data one can collect in a given situation is inevitably limited. Regarding the second issue, we would argue that this is a matter of some responses' not lending themselves to be taken at face value. If someone says, for instance, that a given feature is

13 A reviewer believes to have detected two different notions of anglicism in this study. Specifically, he or she claims that anglicisms are defined as discourse phenomena in the questionnaires, while being treated as belonging to the language system earlier in the paper. Nevertheless, from the start, we have explicitly placed interference phenomena in general (including anglicisms) on the level of discourse, in accordance with Weinreich. It should be noted, however, that this does not prevent us from labeling certain abstract linguistic units as interference phenomena, as long as they only exist as an outcome of interference in the contexts under consideration (e.g., the case of actual $_{\text {angl }}$ in Spanish-speaking contexts, discussed in Section 2, as defined across occurrences).

14 This led us to discard three additional groups of questions originally included in the survey (two from the student questionnaire and one from the instructor questionnaire), as after further consideration we determined that the phrasing of these questions could elicit reports pertaining specifically to particular discursive instances of the features of interest, instead of to the features as such. 
an anglicism, point, blank, and period, that person is implicitly saying that feature only exists as an anglicism. Or, at least, that is the logical implication of such an answer. On the other hand, if a person believes that the feature does exist independently of interferences, the answer to a question asking whether that feature is an anglicism (point, blank, and period) should be negative. ${ }^{15}$ In this regard, it must be pointed out that, even if we agree that the type of methodology used in the present study may increase the chances of responses that are not to be taken at face value, this is an issue even with open-ended questions, where participants can say whatever crosses their minds. Always, individuals may unwittingly provide answers the logical implications of which they would not agree with, or answers that do not quite represent their beliefs and attitudes in a literal way.

Moreover, we tried to avoid interval scales in general in order to avoid central tendency bias as well as to minimize the possibility of low cell counts when performing statistical analyses. We did include options explicitly indicating neutrality and heterogeneity in the items related to classroom attitudes, so that participants would not be forced to report any type of evaluatively marked classroom behavior. In the case of items referring to whether participants consider the features to constitute anglicisms, though we did not allow neutral responses given that these items refer to an objective matter, we gave participants the chance to respond agnostically, so that they would not be forced to make claims about which they were not sure. This was not the case, however, in the items about feature acceptability, where the idea was to force respondents to take a categorical normative stance.

Finally, regarding the reference to English-Spanish translation as well as to writing directly in Spanish in questions about feature acceptability, we included both situations together in an attempt to cover explicitly the two instances of formal use of language the participants were most likely to engage in. In doing this, however, we were aware that we would not be able to distinguish when a participant judged a feature unacceptable in both situations or only in one of them, since individuals may well have a different opinion for each situation.

\section{Results}

\subsection{Overview of Student Responses}

When it comes to the general instructor attitudes perceived by students (Table 1), gerunds and passive constructions elicited, predominantly, responses indicating a generalized negative treatment in the classroom. Responses for prenominal adjectives tended to group in the same option, though much less disproportionally so. In the case of -mente adverbs, responses were fairly evenly distributed across the four options, with that corresponding to heterogeneous attitudes being the most often chosen by a very low margin, while in the case of constructions with poder + infinitive most responses indicated a neutral treatment. In no case did the majority of students report generalized favorable attitudes.

Table 1. Students' responses on general instructor attitudes $(N=430)$.

\begin{tabular}{lrrrr}
\hline & Favorable & Neutral & Unfavorable & Heterogeneous \\
\hline Gerunds & $9(10 \%)$ & $3(4 \%)$ & $60(70 \%)$ & $14(16 \%)$ \\
Prenominal adjectives & $1(1 \%)$ & $17(20 \%)$ & $40(46 \%)$ & $28(33 \%)$ \\
-mente adverbs & $16(19 \%)$ & $23(27 \%)$ & $22(25 \%)$ & $25(29 \%)$ \\
Passive constructions & $3(4 \%)$ & $6(7 \%)$ & $64(74 \%)$ & $13(15 \%)$ \\
poder + infinitive & $7(8 \%)$ & $56(65 \%)$ & $4(5 \%)$ & $19(22 \%)$ \\
\hline
\end{tabular}

When asked about the relation of the features of interest to English (Table 2), most students indicated that they did not consider gerunds, -mente adverbs, or constructions with poder + infinitive

15 Logically speaking, the propositions " $\mathrm{A}$ is an $\mathrm{X}$ " and "A can occur as an $\mathrm{X}$ " are very different. Compare, for example, the sentences $\mathrm{H}_{2} \mathrm{O}$ can occur as an ice cube and $\mathrm{H}_{2} \mathrm{O}$ is an ice cube. 
to be anglicisms. The elements that were most frequently thought to be anglicisms by students were passive constructions, with nearly half of the responses expressing such a belief. Then followed prenominal adjectives, though for these elements the most common response (nearly half of the total too) was that they were not anglicisms. As to agnostic responses, these were rather limited, except for the case of constructions with poder + infinitive.

Table 2. Students' responses to whether the features constitute anglicisms $(N=430)$.

\begin{tabular}{lrrr}
\hline & Yes & No & Not Sure \\
\hline Gerunds & $9(11 \%)$ & $62(72 \%)$ & $15(17 \%)$ \\
Prenominal adjectives & $31(36 \%)$ & $41(48 \%)$ & $14(16 \%)$ \\
-mente adverbs & $7(8 \%)$ & $63(73 \%)$ & $16(19 \%)$ \\
Passive constructions & $41(48 \%)$ & $31(36 \%)$ & $14(16 \%)$ \\
poder + infinitive & $9(11 \%)$ & $45(52 \%)$ & $32(37 \%)$ \\
\hline
\end{tabular}

Finally, when asked to provide their acceptability judgments (Table 3), most students considered gerunds, prenominal adjectives, -mente adverbs, and constructions with poder + infinitive, although, unlike the last two types of elements mentioned, which were deemed acceptable by the large majority of participants, responses for gerunds and prenominal adjectives were rather divided. Passive constructions were the only elements that the majority of students considered not to be acceptable.

Table 3. Students' responses to whether they deemed the features acceptable $(N=430)$.

\begin{tabular}{lrr}
\hline & Yes & No \\
\hline Gerunds & $46(53 \%)$ & $40(47 \%)$ \\
Prenominal adjectives & $47(55 \%)$ & $39(45 \%)$ \\
-mente adverbs & $76(88 \%)$ & $10(12 \%)$ \\
Passive constructions & $33(38 \%)$ & $53(62 \%)$ \\
poder + infinitive & $77(90 \%)$ & $9(10 \%)$ \\
\hline
\end{tabular}

\subsection{Overview of Instructor Responses}

When it comes to instructors' self-reported classroom treatment of the features (Table 4), both in the case of -mente adverbs and in that of passive constructions, but most notably in the former case, the majority of participants admitted to generally displaying unfavorable attitudes. In the case of gerunds this was also the most common response, appearing in almost half of the cases. On the other hand, responses for prenominal adjectives and constructions with poder + infinitive in most cases indicated a generally neutral behavior. In no case did we find a majority of responses indicating a generally positive treatment of a feature.

Table 4. Instructors' responses on the attitudes they tend to display in the classroom $(N=85)$.

\begin{tabular}{lrrr}
\hline & Favorable & Neutral & Unfavorable \\
\hline Gerunds & $5(29 \%)$ & $4(24 \%)$ & $8(47 \%)$ \\
Prenominal adjectives & $3(18 \%)$ & $11(65 \%)$ & $3(17 \%)$ \\
-mente adverbs & $1(6 \%)$ & $4(23 \%)$ & $12(71 \%)$ \\
Passive constructions & $2(12 \%)$ & $6(35 \%)$ & $9(53 \%)$ \\
poder + infinitive & $2(12 \%)$ & $12(70 \%)$ & $3(18 \%)$ \\
\hline
\end{tabular}

In the case of instructors' beliefs about the relation of the features (Table 5), again, passive constructions were the elements that were most often thought to be anglicisms. In this case, however, the number of responses labeling these elements as anglicisms was much higher than in the case of students. For all other features, the majority of respondents did not find the label of anglicism suitable, 
the most divided results being those of constructions with poder + infinitive. Agnostic responses were even fewer this time.

Table 5. Instructors' responses to whether the features constitute anglicisms $(N=85)$.

\begin{tabular}{lrrr}
\hline & Yes & No & Not Sure \\
\hline Gerunds & $5(29 \%)$ & $11(65 \%)$ & $1(6 \%)$ \\
Prenominal adjectives & $3(18 \%)$ & $13(76 \%)$ & $1(6 \%)$ \\
-mente adverbs & $3(18 \%)$ & $12(70 \%)$ & $2(12 \%)$ \\
Passive constructions & $13(76 \%)$ & $4(24 \%)$ & $0(0 \%)$ \\
poder + infinitive & $8(47 \%)$ & $9(53 \%)$ & $0(0 \%)$ \\
\hline
\end{tabular}

This time, when asked to provide their acceptability judgments (Table 6), the majority of instructors deemed all five grammatical features acceptable. The only case where responses where somewhat divided was in that of passive constructions, something that does not come as unexpected considering the responses that have been examined so far.

Table 6. Instructors' responses to whether they deemed the features acceptable $(N=85)$.

\begin{tabular}{lrr}
\hline & Yes & No \\
\hline Gerunds & $12(71 \%)$ & $5(29 \%)$ \\
Prenominal adjectives & $11(65 \%)$ & $6(35 \%)$ \\
-mente adverbs & $14(82 \%)$ & $3(18 \%)$ \\
Passive constructions & $10(59 \%)$ & $7(41 \%)$ \\
poder + infinitive & $13(76 \%)$ & $4(24 \%)$ \\
\hline
\end{tabular}

\subsection{Stigmatization/Xenofication Scores}

Taking the responses obtained from the two groups jointly, and in order to facilitate their interpretation, a scoring system was created to assess the degree of stigmatization and xenofication of the different grammatical features considered among Chilean translation students and instructors.

To that effect, each feature was assigned a score from 0-10, with up to one decimal, in six items (Table 7). Each item corresponds to a group of questions from one of the questionnaires (e.g., questions asking students about general instructor attitudes), and each score is based on the percentage of participants that chose the option considered (most) indicative of stigmatization and/or xenofication in each case. In questions asking students about general instructor attitudes, this option was "In general, my instructors have discouraged the use of $X$ in Spanish or have shown an unfavorable attitude toward this type of forms/constructions." In questions asking instructors about their own attitudes in the classroom, it was "In general, I discourage the use of X in Spanish or show an unfavorable attitude toward this type of forms/constructions with my students." In all questions asking participants whether the features constitute anglicisms or whether they deemed the features acceptable, it was "Yes" and "No," respectively. Thus, each feature could receive a total stigmatization/xenofication (S/X) score of up to 60 points—-the higher the score, the higher the stigmatization/xenofication. ${ }^{16}$

$16 \mathrm{~S} / \mathrm{X}$ scores are presented as a compound measure of the perception and treatment of the target elements, merging the concepts of stigmatization and xenofication into a single, broader concept. Thus, these scores do tell us not about the stigmatization and xenofication of the target elements separately, but only in the aggregate. The rationale for this, other than practical convenience, is that stigmatization and xenofication, as expected, are closely related in the data. 
Table 7. S/X scores.

\begin{tabular}{lccccccc}
\hline & $\mathbf{I 1}^{\mathbf{a}}$ & $\mathbf{I}^{\mathbf{b}}$ & $\mathbf{I 3}^{\mathbf{c}}$ & $\mathbf{I 4}^{\mathbf{d}}$ & $\mathbf{I 5}^{\mathbf{e}}$ & $\mathbf{I 6}^{\mathbf{f}}$ & Total Score $^{\mathbf{c}}$ \\
\hline Gerunds & 7.0 & 1.1 & 4.7 & 4.7 & 2.9 & 2.9 & 23.3 \\
Prenominal adjectives & 4.6 & 3.6 & 4.5 & 1.7 & 1.8 & 3.5 & 19.7 \\
-mente adverbs & 2.5 & 0.8 & 1.2 & 7.1 & 1.8 & 1.8 & 15.2 \\
Passive constructions & 7.4 & 4.8 & 6.2 & 5.3 & 7.6 & 4.1 & 35.4 \\
poder + infinitive & 0.5 & 1.1 & 1.0 & 1.8 & 4.7 & 2.4 & 11.5 \\
\hline
\end{tabular}

a Corresponds to questions asking students about general instructor attitudes. ${ }^{\mathrm{b}}$ Corresponds to questions asking students whether the features constitute anglicisms. ${ }^{\mathrm{C}}$ Corresponds to questions asking students about their acceptability judgments. ${ }^{\mathrm{d}}$ Corresponds to questions asking instructors about their own attitudes in the classroom. ${ }^{\mathrm{e}}$ Corresponds to questions asking instructors whether the features constitute anglicisms. ${ }^{\mathrm{f}}$ Corresponds to questions asking instructors about their acceptability judgments.

As can be seen in Table 7, which shows the scores received by the five features, passive constructions received the highest score of all, corresponding to $59 \%$ of the total possible score. In second place follow, from a very respectable distance, gerunds, with a score corresponding to $39 \%$ of the total possible, and then prenominal adjectives, -mente adverbs, and constructions with poder + infinitive, respectively, all with fairly similarly spaced scores.

\subsection{Examining the Association of Purported Relation to English with Acceptability and Classroom Attitudes}

In order to determine if the participants' acceptability judgments tended to change based on whether they considered the features to constitute anglicisms, we examined, in both groups, the proportion of positive and negative judgments when participants thought the features constituted anglicisms versus when they either thought they did not or were not sure. As shown in Figure 1, in which agnostic responses appear collapsed with responses labeling the features as anglicisms, participants tended to provide negative acceptability judgments when they thought the features constituted anglicisms, while they tended to provide positive judgments when they thought the features did not constitute anglicisms or were not sure about their relation to English.

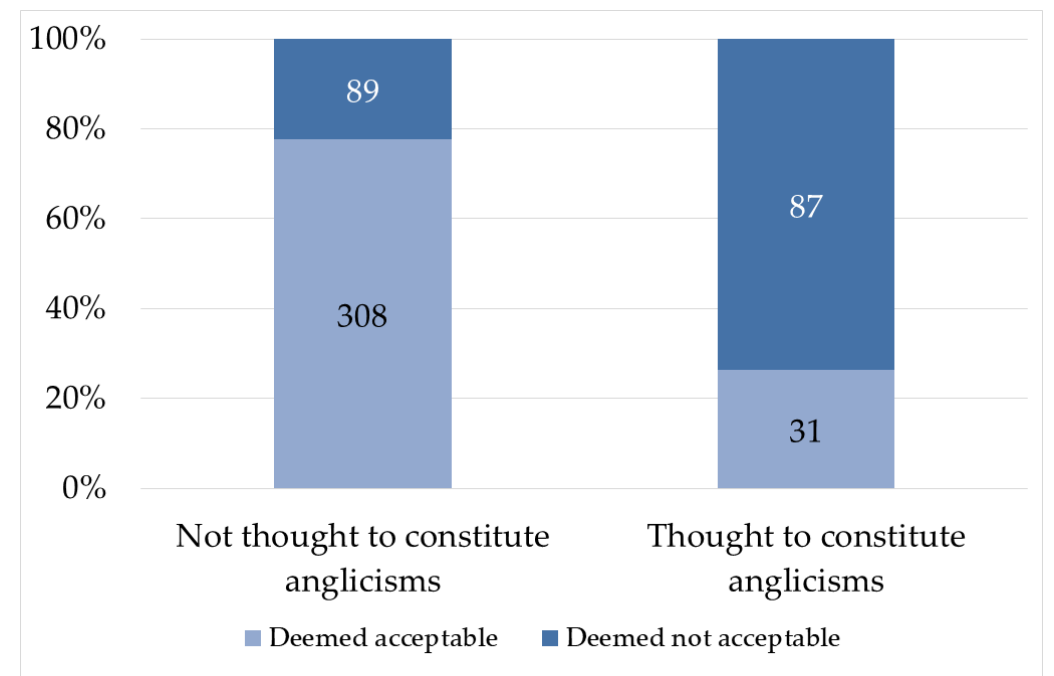

Figure 1. Feature acceptability as a function of purported relation to English.

When looking at instructors' self-reported reported classroom attitudes as a function of their responses to whether the features constituted anglicisms, a parallel situation is observed. As shown in Figure 2, instructors tended to report mostly unfavorable attitudes on their part toward elements 
they believed to constitute anglicisms, whereas when they thought the features did not constitute anglicisms or were not sure they tended to report mostly favorable or neutral attitudes ${ }^{17}$.

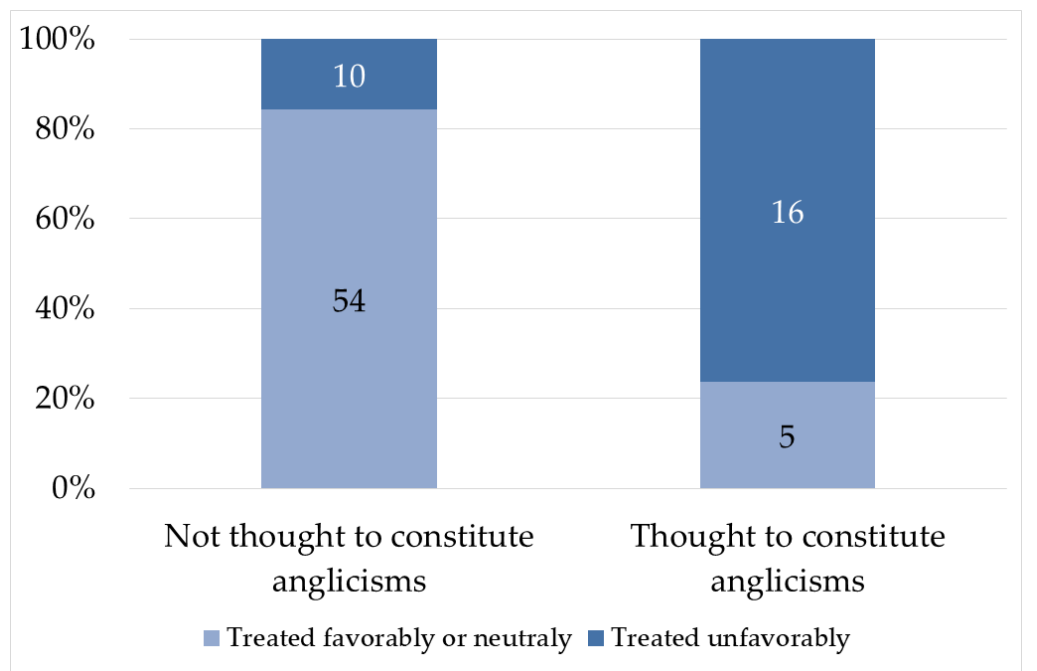

Figure 2. Classroom treatment reported by instructors as a function of purported relation to English.

Two Pearson chi-squared tests of independence conducted using Holm-Bonferroni-adjusted $p$ values ( $\alpha=0.05$ throughout the paper) showed a significant association of feature acceptability with purported relation to English among participants in general $\left(\chi^{2}[1, N=515]=104.19, p<0.001\right.$, $\left.p^{\prime}<0.001\right)$ and with self-reported instructor attitudes $\left(\chi^{2}[1, N=85]=24.54, p<0.001, p^{\prime}<0.001\right) .{ }^{18}$ Thus, whether or not participants agree to label a feature as an anglicism reliably predicts whether they will judge that feature as acceptable or unacceptable. Specifically, when participants responded that they considered a feature to be an anglicism, they were much more likely to provide a negative judgment. In other words, stigmatization and xenofication seem to go hand-in-hand in the population under study, something that can be taken as a measure of internal validity given what we know about the way interference tends to be perceived.

\subsection{Comparing the Responses Elicited by the Different Features}

With the purpose of determining whether the different types of linguistic elements considered elicited significantly different responses, a series of chi-squared tests of independence were performed comparing responses for each feature, again using Holm-Bonferroni-adjusted $p$ values. Acceptability judgments and responses to whether the features constituted anglicisms were examined with two tests, considering students and instructors together. For responses on instructors' behavior in the classroom, two different tests were performed for students and instructors, as the questions asked to the two groups were essentially different; Monte Carlo simulation was used in the case of instructors. A significant association was found between feature and response in all four tests $\left(\chi^{2}[12, N=430]=\right.$ 183.69, $p<0.001, p^{\prime}<0.001$ for students' responses on instructor behavior; $\chi^{2}[N=85]=20.40, p=0.008$, $p^{\prime}=0.008$ for instructors' responses on their own behavior in the classroom; $\chi^{2}[8, N=515]=81.55$, $p<0.001, p^{\prime}<0.001$ for overall responses to whether the features constitute anglicisms; $\chi^{2}[4, N=515]$ $=77.37, p<0.001, p^{\prime}<0.001$ for overall acceptability judgments).

In order to limit to some extent the number of statistical tests performed, and taking into account Echeverría Arriagada's (2016a) results and discussion, as well the results presented in the previous

17 Here we only considered instructors' responses about their own classroom behavior considering that students' responses on their instructors' attitudes correspond to subjective impressions of the cumulative behavior of several individuals.

18 All statistical tests were performed with R (R Core Team 2019). 
subsections, we conducted a series of post-hoc tests comparing the responses for passive constructions with those for each of the other features. Once more, Holm-Bonferroni-adjusted $p$ values were used.

As Table 8 shows, a significant association was found between feature and response in 8 out of 16 tests performed, indicating significantly different responses for passive constructions and the respective features considered in each of those cases. Nevertheless, we should take into consideration that half of the tests that did not yield a significant result corresponded to the tests performed on instructors' responses on their own behavior in the classroom, where the number of observations went considerably lower. If we set aside these tests considering this factor, we obtain a significant difference in eight out of 12 comparisons, all other non-significant results corresponding to comparisons with the two features immediately following passive constructions in S/X scores, namely gerunds and prenominal adjectives.

Table 8. Post-hoc comparisons between responses for passive constructions and responses for the other features.

\begin{tabular}{|c|c|c|c|c|}
\hline Comparison & $x^{2}$ & DF & $p$ & $p^{\prime}$ \\
\hline \multicolumn{5}{|l|}{$\begin{array}{l}\text { Students' responses on instructor classroom behavior } \\
(N=172 \text { in each test })\end{array}$} \\
\hline Passive constructions vs. gerunds ${ }^{a}$ & 4.17 & N/A & 0.26 & 0.78 \\
\hline Passive constructions vs. prenominal adjectives ${ }^{a}$ & 17.29 & $\mathrm{~N} / \mathrm{A}$ & $<0.001$ & $0.009 * *$ \\
\hline Passive constructions vs. -mente adverbs & 43.16 & 3 & $<0.001$ & $<0.001^{* * *}$ \\
\hline Passive constructions vs. poder + infinitive ${ }^{\text {a }}$ & 98.86 & N/A & $<0.001$ & 0.0050 ** \\
\hline \multicolumn{5}{|l|}{$\begin{array}{l}\text { Instructors' responses on their own behavior in the } \\
\text { classroom ( } N=34 \text { in each test) }\end{array}$} \\
\hline Passive constructions vs. gerunds ${ }^{a}$ & 1.74 & N/A & 0.53 & 1 \\
\hline Passive constructions vs. prenominal adjectives ${ }^{a}$ & 4.67 & $\mathrm{~N} / \mathrm{A}$ & 0.13 & 0.50 \\
\hline Passive constructions vs. -mente adverbs a & 1.16 & $\mathrm{~N} / \mathrm{A}$ & 0.55 & 1 \\
\hline Passive constructions vs. poder + infinitive ${ }^{\text {a }}$ & 5.00 & $\mathrm{~N} / \mathrm{A}$ & 0.09 & 0.46 \\
\hline \multicolumn{5}{|l|}{$\begin{array}{l}\text { Overall responses to whether the target elements } \\
\text { constitute anglicisms }(N=206 \text { in each test) }\end{array}$} \\
\hline Passive constructions vs. gerunds & 37.03 & 2 & $<0.001$ & $<0.001 * * *$ \\
\hline Passive constructions vs. prenominal adjectives & 8.64 & 2 & 0.01 & 0.11 \\
\hline Passive constructions vs. -mente adverbs & 45.30 & 2 & $<0.001$ & $<0.001^{* * *}$ \\
\hline Passive constructions vs. poder + infinitive & 30.38 & 2 & $<0.001$ & $<0.001 * * *$ \\
\hline \multicolumn{5}{|l|}{ Overall acceptability judgments ( $N=206$ in each test) } \\
\hline Passive constructions vs. gerunds & 3.81 & 1 & 0.05 & 0.36 \\
\hline Passive constructions vs. prenominal adjectives & 3.81 & 1 & 0.05 & 0.36 \\
\hline Passive constructions vs. -mente adverbs & 44.90 & 1 & $<0.001$ & $<0.001 * * *$ \\
\hline Passive constructions vs. poder + infinitive & 44.90 & 1 & $<0.001$ & $<0.001 * * *$ \\
\hline
\end{tabular}

${ }^{a}$ Monte Carlo simulation was used. ${ }^{* *} \leq 0.01 ; * * * 0.001$.

\subsection{Summary and Discussion}

In the preceding subsections, numerous responses have been examined, from both students and instructors, labeling the features under consideration as unacceptable and/or as anglicisms, as well as indicating generalized unfavorable instructor attitudes toward these features in the classroom. Furthermore, a significant association was found between feature acceptability and both purported relation to English and self-reported instructor attitudes in the classroom, such that when a feature was labeled as an anglicism it would most likely elicit a negative judgment.

If we take participants' responses at face value, these findings can be taken to suggest a process of stigmatization and xenofication, by which certain linguistic features have gone from being known to be related to anglicisms, to becoming subject to negative bias and to being treated as if they were anglicisms in themselves. As suggested earlier, however, not all responses lend themselves to be taken at face value, something that may become even more of an issue with the type of methodology used in this study, so we should be cautious when drawing conclusions. Still, this is the direction in which the data point. Moreover, it would seem overly pessimistic to assume that none of the responses that were collected are to be taken at face value. In any case, an alternative, more conservative interpretation of 
the results can be one in which the stigmatization and xenofication that seem to be captured in the participants' responses comes from a strong association of some of the features with a negative value and with the idea of anglicism in the minds of some individuals. Such an association does not have to involve the belief that every possible occurrence of the feature in question will correspond to an unacceptable anglicism. It may well be, for example, that an individual has simply grown used to witnessing anglicized uses of these features or their phonic forms that he or she considers reprehensible (normatively, stylistically, communicatively, etc.).

Whether it be one thing or the other, the most striking case under examination when it comes to apparent stigmatization and xenofication is clearly that of passive constructions. Indeed, passive constructions received a S/X score of 59\% (the highest by a fairly wide margin and the only one higher than half of the total possible score), and responses for this feature were found to be significantly different from those for the other features in eight out of 12 post-hoc pairwise comparisons, setting aside instructors' responses on their own behavior in the classroom given the low number of observations available in this case. This finding is consistent with the evaluation and substitution rate reported for these elements in Echeverría Arriagada's (2016a) study, as well as with the frequency with which translators have been historically warned about them in the literature dealing with English-Spanish translation, including by the Royal Spanish Academy, ${ }^{19}$ undoubtedly the most important symbol of authority when it comes to the Spanish language.

Now, passive constructions may be the most striking case, but responses suggesting stigmatization and xenofication were not rare in the case of gerunds and pronominal adjectives either. As for -mente adverbs, a non-negligible number of reports of unfavorable instructor attitudes was recorded, especially from instructors themselves; however, few participants considered these forms to be anglicisms or to not be acceptable as a class. Constructions with poder + infinitive, on the other hand, besides being labeled as anglicisms or being judged as unacceptable only by few participants, elicited a very small number of reports of unfavorable classroom attitudes. As to exactly what factors may determine the degree of stigmatization and xenofication of a particular feature, various possibilities spring to mind. As suggested above, warning frequency seems to have a role. Other possibilities are feature frequency (both in translations and in general), the frequency of actual interference phenomena related to a feature, and perceptual salience. However, this is for future studies to say.

Another aspect that deserves some commentary is the existence of an apparent discrepancy, in certain cases, between instructors' classroom behavior, on the one hand, and their acceptability judgments and their beliefs on the relation of the features to English, on the other hand. This occurs in the case of gerunds, where $70 \%$ of students reported that their instructors tended to display negative attitudes toward these forms and $47 \%$ of instructors admitted to exhibiting such behavior in the classroom, but where only $2.8 \%$ of the latter group delivered negative judgments and the same percentage considered these forms to constitute anglicisms. Additionally, the same type of discrepancy is found, perhaps more strikingly, in the case of -mente adverbs. Here, only $25 \%$ of students reported generalized negative attitudes on the part of their instructors, yet $71 \%$ of instructors reported that they did tend to display such attitudes in the classroom, although merely $1.8 \%$ of them delivered negative judgments and the same percentage considered these forms to constitute anglicisms.

Such a discrepancy might be partially explained, as far instructor responses are concerned, by the number of instructors participating in the study. It could also be that instructors too often see their students use gerunds and -mente or the corresponding phonic forms (possibly due to English influence in some cases, but not necessarily) in ways they consider reprehensible, so the unfavorable treatment reported corresponds not to any prejudice toward these forms, but simply to instructors' frequent attempts to correct their students' errors. Alternatively, and certainly more worrisomely, it could be

19 "French and English use the passive [ . . . ] in proportions much higher than our language. It is convenient that translators bear this preference in mind, in order to avoid stylistic shortcomings and even grammatical errors" (RAE = Real Academia Española 1973, p. 451). 
that, in some cases, instructors are generically discouraging the use of these forms or tend to show an unfavorable attitude toward them as a preventive measure, anticipating particular uses they deem incorrect or abnormal. This does not seem far-fetched, as this type of practice can be found even in published language guides. Consider, for instance, the following passage by Iguina and Dozier (2008):

The passive voice is used much more in English than in Spanish, where it is found mostly in literary contexts. The passive voice in Spanish is used with increasing frequency in journalistic prose, but this is considered the result of literal translation from English. For those who are not yet experts in the language, it is best to avoid the passive voice in Spanish (p. 84).

Thus, the fear of interference that has been reported in some translation trainees (see Kussmaul 1995, pp. 17-20) could sometimes come directly from instructors, though this possibility is to be further evaluated.

\section{Conclusions}

In this paper, we have investigated the possibility that the perception and treatment of certain interference phenomena may extend to native linguistic features holding an extrinsic relation to said phenomena. After examining the perception and treatment of Spanish features commonly associated with anglicisms in the Chilean translator training context, such a possibility does not seem too unlikely. Even if we decide not to take participants' responses at face value, our data at the very least show that some students and instructors tend to strongly associate certain features with a negative value and with the idea of anglicism. This association may or may not involve a categorical stigmatization and xenofication of the respective features; but, either way, this is likely to have a noticeable impact on translation and language use in general, as well as on pedagogic practices.

Evidently, given that we focused strictly on translation students and instructors, it is impossible to say with certainty whether this phenomenon is specific to translator training or whether it is something that we would also find in other pedagogic environments, or even outside the classroom. After all, warnings about some of the features we have looked at in this paper are sometimes also found in general language and style guides. In any case, irrespective of whether or not we would find an analogous or similar situation in different types of contexts, we consider our findings to be worthy of attention from a translator training perspective, as they indicate a possible stigmatization and xenofication of potentially useful linguistic resources in translator training, something that may have negative consequences for trainees.

As far as instructor behavior is concerned, these consequences could emerge even where there is no indication that individuals may categorically perceive the respective features negatively or as anglicisms. In particular, this could happen if instructors were generically discouraging the use of these forms or tended to show an unfavorable attitude toward them, a behavior that could correspond to a preventive measure to avoid certain uses that are seen as reprehensible (due to English influence or otherwise). In this connection, it seems pertinent to cite the following passage by Nicolás González Ruiz, which, though in a different context, deals precisely with one of the features considered in the present study, namely the gerund:

The gerund is often used incorrectly. So deep is the conviction of this fact, that it has come to cause another: the fact that many make strenuous efforts to avoid the gerund when writing, as though they were contemplating a dangerous landscape and preferred to go around it in order to avoid walking through it. But detours are never a good writing procedure. It is possible to navigate through obstacles without problems knowing what and where the obstacles are (Martín Vivaldi 2000, pp. 61-62).

Of course, the preventive mechanism we are hypothesizing in the case of translation instructors concerns not these individuals' own linguistic output, but somebody else's, namely their students'. Nonetheless, the metaphor at the end of the quoted passage seems fitting. Indeed, if an instructor 
wants to prevent students from making odd or incorrect use of certain linguistic features (or of the corresponding phonic forms), efforts should be directed at making students actually learn when and how to use those features, instead of simply getting rid of them, which would deprive trainees from legitimate expressive possibilities historically available to speakers of the language. Still, it is for future studies to say whether such a preventive behavior is at the root of the discrepancy found between instructors' reported classroom behavior and their acceptability judgments and beliefs on the relation of the features under consideration to English.

In concluding, we hope this study can draw the attention of researchers and educators to this largely unexplored topic, which in our opinion would be worth addressing from new perspectives. For example, it would be useful to directly observe and document both students' and instructors' behavior in the translation classroom as it pertains to linguistic features that are likely candidates for stigmatization and xenofication due to their (purported) relation to interference phenomena. It would also be worthwhile to determine in what cases such stigmatization and xenofication is more likely, if at all, to affect the actual linguistic choices of students. Likewise, it would be interesting to know if anything similar occurs in the case of other language pairs, or even in other comparable situations involving the same working languages, for instance by looking at translation training in other Spanish-speaking countries.

Supplementary Materials: The main content of the questionnaires and the analyzed data are available online at http://www.mdpi.com/2226-471X/4/2/42/s1.

Author Contributions: Conceptualization: C.I.E.; methodology: C.I.E. and C.A.G.-F.; resources: C.I.E. and C.A.G.-F.; validation: C.I.E.; formal analysis: C.I.E.; investigation: C.A.G.-F.; data curation: C.I.E.; writing-original draft preparation: C.I.E.; writing-review and editing: C.I.E. and C.A.G.-F.; visualization: C.I.E.; funding acquisition: C.I.E.

Funding: This research was funded by a grant from the Universidad Chileno-Británica de Cultura.

Acknowledgments: The authors wish to thank Matthew Carlson, Maike Rocker, and two anonymous reviewers for their comments and suggestions.

Conflicts of Interest: The authors declare no conflict of interest.

\section{References}

Aguado de Cea, Guadalupe. 1990. Interferencias lingüísticas en los textos técnicos. In II Encuentros Complutenses en Torno a la Traducción, 12-16 de Diciembre de 1988. Edited by Margit Readers and Juan Conesa. Madrid: Instituto Universitario de Lenguas Modernas y Traductores, Universidad Complutense, pp. 163-96.

Alarcos Llorach, Emilio. 1969. Gramática Estructural, Según la Escuela de Copenhague y con Especial Atención a la Lengua Española. Madrid: Gredos.

Alarcos Llorach, Emilio. 1999. Gramática de la Lengua Española. Madrid: Espasa Calpe.

Alcaraz Varó, Enrique, and María Antonia Martínez Linares. 1997. Diccionario de Lingüística Moderna. Barcelona: Ariel.

Anderman, Gunilla, and Margaret Rogers, eds. 2005. In and out of English: For Better, for Worse? Clevedon: Multilingual Matters.

Arauz, Pedro. 1992. Errores frecuentes en la traducción. In Actas de las I Jornadas Internacionales de Inglés Académico, Técnico y Profesional: Investigación y Enseñanza. Edited by Sebastián Barrueco, Lina Sierra and María José Sánchez. Alcalá de Henares: Servicio de Publicaciones de la Universidad de Alcalá de Henares, pp. 179-83.

Blas Arroyo, José Luis. 1991. Problemas teóricos en el estudio de la interferencia lingüística. Revista Española de Lingüística 21: 265-90.

Bosque, Ignacio, and Violeta Demonte, eds. 1999. Gramática Descriptiva de la Lengua Española. 3 vols, Madrid: Espasa Calpe.

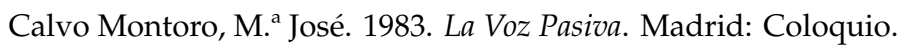

Castillo Lluch, Mónica. 2005. Translación y variación lingüística en Castilla (siglo XIII): La lengua de las traducciones. Cahiers d'Études Hispaniques Médiévales 28: 131-44. [CrossRef] 
Claros Díaz, M. Gonzalo. 2016. Cómo Traducir y Redactar Textos Científicos en Español: Reglas, Ideas y Consejos. Barcelona: Fundación Dr. Antonio Esteve.

Company Company, Concepción. 2012. Condicionamientos textuales en la evolución de los adverbios en -mente. Revista de Filología Española 92: 9-42. [CrossRef]

Coseriu, Eugenio. 1977. Sprachliche Interferenz bei Hochgebildeten. In Sprachliche Interferenz: Festschrift für Werner Betz. Edited by Herbert Kolb and Hartmut Laufferpp. Tübingen: Max Niemeyer Verlag, pp. 77-100.

Coseriu, Eugenio. 1982a. Determinación y entorno: Dos problemas de una teoría del hablar. In Teoría del Lenguaje y Lingüística General: Cinco Estudios. Madrid: Gredos, pp. 282-323.

Coseriu, Eugenio. 1982b. Sistema, norma y habla. In Teoría del Lenguaje y Lingüística General: Cinco Estudios. Madrid: Gredos, pp. 11-113.

De Saussure, Ferdinand. 2011. Course in General Linguistics. New York: Columbia University Press.

Del Rey Quesada, Santiago. 2017. (Anti-)Latinate syntax in Renaissance dialogue: Romance translations of Erasmus's Uxor Mempsigamo. Zeitschrift für romanische Philologie 133: 673-708. [CrossRef]

Domínguez de Rodríguez-Pasques, Petrona. 1970. Morfología y sintaxis del adverbio en -mente. In Actas del Tercer Congreso Internacional de Hispanistas. Edited by Carlos Magis. México: El Colegio de México, pp. 293-303.

Echeverría Arriagada, Carlos I. 2011. Sobre el uso de adverbios en -mente en la traducción inglés-castellano. Paper presented at the XI Congreso Nacional de Estudiantes de Traducción e Interpretación, Valparaíso, Chile, October 27-28.

Echeverría Arriagada, Carlos I. 2016a. Actitudes y preferencias de estudiantes de traducción inglés-español frente a recursos gramaticales del español asociados a anglicismos de frecuencia. Estudios Filológicos 58: 67-96. [CrossRef]

Echeverría Arriagada, Carlos I. 2016b. La interferencia lingüística de frecuencia. Boletín de Filología 51: 93-115. [CrossRef]

Franco Aixelá, Javier. 2019. BITRA—Bibliography of Interpreting and Translation. Available online: http: //dti.ua.es/en/bitra/introduction.html (accessed on 12 April 2019).

García González, José Enrique. 1998. Anglicismos morfosintácticos en la traducción periodística (inglés-español): Análisis y clasificación. Cauce 20-21: 593-622.

García Yebra, Valentín. 1984. Teoría y Práctica de la Traducción. Madrid: Gredos.

García Yebra, Valentín. 1985. Traducción y Enriquecimiento de la Lengua del Traductor: Discurso Leído el Día 27 de Enero de 1985. Madrid: Real Academia Española.

Gili Gaya, Samuel. 1980. Curso Superior de Sintaxis Española. Barcelona: Vox.

Granger, Sylviane, and Helen Swallow. 1988. False friends: A kaleidoscope of translation difficulties. Langage et l'Homme 23: 108-20.

Iguina, Zulma, and Eleanor Dozier. 2008. Manual de Gramática: Grammar Reference for Students of Spanish. Boston: Thomson Heinle.

Jaspert, Nikolas. 2015. An introduction to discourses of purity in transcultural perspective. In Discourses of Purity in Transcultural Perspective (300-1600). Edited by Matthias Bley, Nikolas Jaspert and Stefan Köck. Leiden: Brill, pp. 1-20.

Kabatek, Johannes. 1997. Zur Typologie sprachlicher Interferenzen. In Neue Forschungsarbeiten zur Kontaktlinguistik. Edited by Wolfgang W. Moelleken and Peter J. Weber. Bonn: Dümmler, pp. 232-41.

Kellerman, Eric, and Michael Sharwood Smith, eds. 1986. Crosslinguistic Influence in Second Language Acquisition. Oxford: Pergamon Press.

Koessler, Maxime, and Jules Derocquigny. 1928. Les Faux Amis, ou les Trahisons du Vocabulaire Anglais. Paris: Libraire Vuibert.

Kussmaul, Paul. 1995. Training the Translator. Amsterdam: John Benjamins.

Lázaro Carreter, Fernando. 1997. El Dardo en la Palabra. Barcelona: Galaxia Gutenberg.

López Guix, Juan Gabriel, and Jacqueline Minett Wilkinson. 1997. Manual de Traducción. Barcelona: Gedisa.

Lorenzo, Emilio. 1991. Anglicismos y traducciones. In Studia Patriciae Shaw Oblata: Quinque Magisterii Lustris Apud Hispaniae Universitates Peractis. Edited by Santiago González y Fernández-Corugedo, Juan E. Tazón Salces, María Socorro Suárez Lafuente, Isabel Carrera Suárez and Virginia Prieto López. Oviedo: Universidad de Oviedo, vol. 1, pp. 67-79.

Lorenzo, Emilio. 1996. Anglicismos Hispánicos. Madrid: Gredos.

Lorian, Al. 1967. Les latinismes de syntaxe en français. Zeitschrift für französische Sprache und Literatur 77: 155-69. 
Marcos Pérez, Pedro Jesús. 1971. Los Anglicismos en el Ámbito Periodístico: Algunos de los Problemas que Plantean. Valladolid: Universidad de Valladolid.

Martín Vivaldi, Gonzalo. 2000. Curso de Redacción: Teoría y Práctica de la Composición y del Estilo. Madrid: Thomson. Molina Plaza, Silvia. 1995. Anglicismos léxicos y sintácticos en la traducción literaria de textos del inglés al español. In La Palabra Vertida. Investigaciones en Torno a la Traducción: Actas de los VI Encuentros Complutenses en Tomo a la Traducción. Edited by Rafael Martín-Gaitero and Miguel Ángel Vega. Madrid: Editorial Complutense, pp. 621-28.

Montes, José Joaquín. 2002. La actual crisis de la voz pasiva en español. Boletín de Filología 39: 103-21.

Musacchio, María Teresa. 2005. The influence of English on Italian: The case of translations of economic articles. In In and out of English: For Better, for Worse? Edited by Gunilla Anderman and Margaret Rogers. Clevedon: Multilingual Matters, pp. 71-96.

Newmark, Peter. 1988. A Textbook of Translation. New York: Prentice Hall.

Newmark, Peter. 1991. About Translation. Clevedon: Multilingual Matters.

Odlin, Terence. 1989. Language Transfer: Cross-linguistic Influence in Language Learning. Cambridge: Cambridge University Press.

Pratt, Chris. 1980. El Anglicismo en el Español Peninsular Contemporáneo. Madrid: Gredos.

R Core Team. 2019. R: A Language and Environment for Statistical Computing. Available online: https: //www.R-project.org (accessed on 12 April 2019).

Rabadán, Rosa, Belén Labrador, and Noelia Ramón. 2006. Putting meanings into words: English '-ly' adverbs in Spanish translation. In Studies in Contrastive Linguistics: Proceedings of the 4th International Contrastive Linguistics Conference. Edited by Cristina Mourón Figueroa, Moralejo Gárate and Teresa Iciar. Santiago de Compostela: Servicio de Publicaciones, Universidade de Santiago de Compostela, pp. 855-62.

RAE = Real Academia Española. 1973. Esbozo de una Nueva Gramática de la Lengua Española. Madrid: Espasa-Calpe.

RAE/ASALE = Real Academia Española and Asociación de Academias de la Lengua Española. 2009. Nueva Gramática de la Lengua Española. Madrid: Espasa Calpe.

Ramón, Noelia, and Belén Labrador. 2008. Translations of '-ly' adverbs of degree in an English-Spanish parallel corpus. Target 20: 275-96. [CrossRef]

Rochel, Guy, and María Nieves Pozas Ortega. 2008. Dificultades Gramaticales de la Traducción al Francés. Barcelona: Ariel.

Rodríguez Medina, María Jesús. 2002. Los anglicismos de frecuencia sintácticos en español. Revista Española de Lingüística Aplicada 15: 149-70.

Serna, Ven. 1970. Breve examen de unos anglicismos recientes. In Actas del Tercer Congreso Internacional de Hispanistas. Edited by Carlos Magis. México: El Colegio de México, pp. 839-45.

Smith, Ross. 1997. English in European Spanish. English Today 13: 22-26. [CrossRef]

Toury, Gideon. 1995. Descriptive Translation Studies and Beyond. Amsterdam: John Benjamins.

Vázquez Orta, Ignacio. 1986. Un enfoque sistémico de la comparación de las estructuras oracionales pasivas en inglés y en castellano. In Aspectos Comparativos en la Lengua y Literatura de Habla Inglesa. AEDEAN: Actas del IX Congreso Nacional. Edited by Asociación Española de Estudios Anglo-Norteamericanos. Murcia: Asociación Española de Estudios Anglo-Norteamericanos and Departamento de Filología Inglesa, Universidad de Murcia, pp. 203-14.

Vázquez-Ayora, Gerardo. 1977. Introducción a la Traductología: Curso Básico de Traducción. Washington: Georgetown University Press.

Véliz Ojeda, Eduardo, and Víctor Cámara Cámara. 2010. La "parataxis" como anglicismo de frecuencia en traducciones del inglés al castellano: Análisis desde los estudios culturales. Paper presented at the XI Congreso Nacional de Estudiantes de Traducción e Interpretación, Copiapó, Chile, October 28-29.

Venuti, Lawrence. 1998. The Scandals of Translation: Towards an Ethics of Difference. London: Routledge. Weinreich, Uriel. 1968. Languages in Contact: Findings and Problems. The Hague: Mouton.

(C) 2019 by the authors. Licensee MDPI, Basel, Switzerland. This article is an open access article distributed under the terms and conditions of the Creative Commons Attribution (CC BY) license (http://creativecommons.org/licenses/by/4.0/). 